\title{
KURANG ENERGI KRONIS BERHUBUNGAN DENGAN KEJADIAN ANEMIA PADA IBU HAMIL
}

\author{
Subriah $^{\bowtie}$, Inka Dewi Safitri, Syaniah Umar, Djuhadiah Saadong \\ Jurusan Kebidanan Poltekkes Kemenkes Makassar
}

\begin{tabular}{l}
\hline ARTICLE INFO \\
\hline Article history \\
Submitted : 2021-01-28 \\
Revised : 2021-05-20 \\
Accepted : 2021-07-31 \\
Keywords: \\
Anemia events \\
Chronic energy deficiency \\
Pregnant women
\end{tabular}

\section{Kata Kunci:}

Ibu hamil

Kejadian anemia

Kurang Energi Kronis

\begin{abstract}
KEK (Chronic Energy Deficiency) is a condition caused by an imbalance in nutritional intake, which lasts (chronic) while the anemia in pregnant women is closely related to the nutritional status of pregnant women because anemia is one sign that the mother suffers from malnutrition. This study aims to determine the relationship between chronic energy deficiency and anemia in pregnant women at the Public healthcanter Mangasa, Makassar City. The type of research used is an analytic survey with a crosssectional design. The sampling technique was purposive sampling with 78 respondents. The results of the statistical test with the chi-square test are known as the significance value of $p(0.005)<\alpha(0.05)$, meaning that the $p$ value is smaller than the value of $\alpha$ at $95 \%$ confidence level with 1 degree of freedom, it can be concluded that the null hypothesis is rejected and this accepted hypothesis means that there is a chronic lack of energy relationship with the incidence of anemia in pregnant women at the Public healthcenter Mangasa, Makassar City. Therefore, health workers are expected to be able to carry out continuous strengthening of KIE (communication, information, and education) in pregnant women with KEK risk and anemia to pay more attention to their health status from all factors in readiness to face pregnancy with a cross-sectoral approach.

KEK (Kurang Energi Kronik) merupakan kondisi yang disebabkan karena adanya ketidakseimbangan asupan gizi, yang berlangsung menahun (kronis) sedangkan anemia pada ibu hamil erat kaitannya dengan status gizi ibu hamil karena anemia merupakan salah satu tanda bahwa ibu menderita kekurangan gizi. Berdasarkan hasil laporan Riskesdas Tahun 2020 prevalensi KEK di Provinsi Sulawesi Selatan sebesar 13,8\% sedangkan berdasarkan hasil pemantauan gizi di Kota Makassar pada tahun 2018, prevalensi KEK pada ibu hamil sebanyak 2.996 orang ibu hamil. Penelitian ini bertujuan untuk mengetahui hubungan Kurang Energi Kronis dengan kejadian anemia pada ibu hamil di Puskesmas Mangasa Kota Makassar. Jenis penelitian yang digunakan adalah survey analitik dengan rancangan cross sectional. Teknik pengambilan sampel secara purposive sampling dengan 78 responden. Hasil uji statistik dengan chi-square test yaitu diketahui nilai signifikansi $\mathrm{p}(0,005)<\alpha(0,05)$, artinya nilai $\mathrm{p}$ lebih kecil dari nilai $\alpha$ pada derajat kepercayaan $95 \%$ dengan derajat kebebasan 1 , maka dapat disimpulkan bahwa hipotesis nol ditolak dan hipotesis alternatif diterima ini berarti terdapat hubungan kurang energi kronis dengan kejadian anemia pada ibu hamil di Puskesmas Mangasa Kota Makassar. Petugas kesehatan diharapkan dapat melakukan pemantapan KIE yang berkesinambungan pada ibu hamil dengan risiko KEK dan anemia untuk lebih memperhatikan status kesehatannya dari segala faktor dalam kesiapan menghadapi kehamilan dengan pendekatan lintas sektoral.
\end{abstract}

$\triangle$ Corresponding Author:

Subriah

Jurusan Kebidanan Poltekkes Kemenkes Makassar

Telp. 081221433225

Email: subriah@poltekkes-mks.ac.id

\section{PENDAHULUAN}

Secara global perdarahan telah menjadi penyebab utama kematian pada ibu hamil yaitu sebanyak 35\% (WHO, 2015). Sedangkan komplikasi yang paling sering dari perdarahan adalah ibu hamil yang anemia dan status gizi yang buruk (Infodatin, 2014) (Prawirohardjo, 2016).

Masalah Status gizi pada ibu hamil masih merupakan fokus perhatian, masalah tersebut antara lain ibu hamil yang berisiko KEK (Kurang Energi Kronik). Hasil Riskesdas 2018 menyajikan prevalensi KEK wanita hamil 
umur 15 - 49 tahun, di Indonesia masih tinggi yaitu sebanyak 17,3 persen. Prevalensi KEK terendah di Kalimantan Utara $(1,7 \%)$ dan tertinggi di Nusa Tenggara Timur $(36,8 \%)$ sedangkan di Sulawesi Selatan (17,1\%) (RISKESDAS, 2018).

Anemia pada ibu hamil erat kaitannya dengan status gizi ibu hamil karena anemia merupakan salah satu tanda bahwa ibu menderita kekurangan gizi. Anemia pada wanita hamil memiliki dampak yang buruk, baik terhadap ibu maupun janin. Ibu hamil yang menderita anemia berat memungkinkan terjadinya partus premature serta memiliki bayi dengan berat lahir rendah yang dapat mengakibatkan kematian (Kemenkes RI, 2018).

Berdasarkan hasil Riset Kesehatan Dasar (Riskesdas) tahun 2018, terdapat 48,9\% ibu hamil anemia, yaitu ibu hamil dengan kadar Hemoglobin $(\mathrm{Hb})$ kurang dari 11,0 g/dl, dengan proporsi berdasarkan umur $15-24$ tahun $(84,6 \%)$, umur $25-34$ tahun $(33,7 \%)$, umur 35 - 44 (33,6\%), dan umur 45 - 54 (24\%). Tingginya angka tersebut disebabkan antara lain adalah keadaan kesehatan dan gizi ibu yang rendah selama kehamilan.

Berdasarkan hasil laporan Riskesdas Tahun 2020 prevalensi KEK di provinsi Sulawesi Selatan sebesar 13,8\% sedangkan berdasarkan hasil pemantauan gizi di Kota Makassar pada tahun 2018, prevalensi KEK pada ibu hamil sebanyak 2.996 orang ibu hamil yang mengalami Kurang Energi Kronik (KEK). Data kunjungan ibu hamil baru di Puskesmas Mangasa Kota Makassar sebanyak 428 orang pada tahun 2018, didapatkan ibu hamil KEK sebanyak 110 orang dan ibu hamil yang anemia sebanyak 185 orang (Puskesmas Mangasa, 2018).

Hasil survey Pemantauan Status Gizi (PSG) tahun 2016, persentase ibu hamil KEK pada tahun $2016(16,2 \%)$ masih di bawah target yang ditentukan $22,7 \%$. Hasil ini menjadi gambaran status gizi ibu hamil yang sesuai dengan harapan. Apabila dibandingkan hasil PSG antara tahun 2016 dan tahun 2015 terlihat adanya peningkatan persentase ibu hamil kurang energi kronik. Sedangkan pada target yang diharapkan adalah seharusnya terjadi penurunan capaian. Bila dibandingkan dengan target jangka menengah sebesar 21,2\% (2017) ibu hamil KEK, perlu ada strategi baru dalam menurunkan angka ibu hamil KEK (Kemenkes RI, 2017).
Menurut penelitian (Wijayanti, 2016), salah satu faktor-faktor yang berhubungan dengan KEK adalah status anemia. Sedangkan dalam penelitian (Aminin et al., 2014) yaitu diketahui jumlah responden 31 orang dan ternyata didapatkan $11,1 \%$ ibu KEK tetapi tidak anemia. Maka dari itu peneliti tertarik untuk melakukan penelitian tentang hubungan Kekurangan Energi Kronis (KEK) dengan kejadian anemia pada Ibu Hamil di Puskesmas Mangasa Kota Makassar.

\section{METODE PENELITIAN \\ Jenis Penelitian}

Jenis penelitian yang digunakan adalah penelitian survey analitik dengan pendekatan cross sectional.

\section{Lokasi dan Waktu Penelitian}

Penelitian ini dilakukan di wilayah kerja Pusekasmas Mangasa Kota Makassar pada Bulan Maret Tahun 2019.

\section{Populasi dan Sampel}

Populasi dalam penelitian ini adalah semua ibu hamil baru yang melakukan pemeriksaan antenatal di Wilayah Puskesmas Mangasa Kota Makassar periode tahun 2018 sebanyak 428 orang. Besar sampel penelitian ini menggunakan perhitungan rumus Lemeshow sebanyak 78 orang. Teknik sampling yang digunakan adalah purposive sampling pada kurun waktu penelitian selama bulan Maret 2019.

\section{Pengumpulan Data}

Jenis data yang dikumpulkan dan yang digunakan dalam penelitian ini bersumber dari data sekunder. Data sekunder yang dimaksud adalah data yang diperoleh atau telah tersedia di Puskesmas Mangasa Kota Makassar pada tahun 2018.

Instrumen penelitian yang digunakan untuk memperoleh data tentang hubungan Kurang Energi Kronik dengan kejadian anemia pada Ibu Hamil di Puskesmas Mangasa Kota Makassar yaitu dengan menggunakan lembar pengkajian data sekunder.

\section{Pengolahan dan Penyajian Data}

Pengolahan dan penyajian data dilakukan dengan menggunakan komputer program SPSS. Diawali dengan proses pemeriksaan data, pemberian kode, penginputan, dan yang terakhir adalah tabulasi. 


\section{Analisis Data}

Uji statistik yang digunakan untuk mengetahui hubungan Kurang Energi Kronis dengan kejadian anemia pada Ibu Hamil di Puskesmas Mangasa Kota Makassar, yaitu uji statistik Chis-quare.

\section{HASIL PENELITIAN}

Pada tabel 1 menunjukkan bahwa ibu hamil berjumlah 78 orang. Kelompok umur berisiko ( $<20$ tahun atau $>35$ tahun) sebanyak 25 ibu hamil $(32,1 \%)$ dan kelompok umur yang tidak berisiko 20 - 35 tahun sebanyak 53 ibu hamil $(67,9 \%)$. Kelompok paritas yang berisiko (lebih dari 4) sebanyak 14 ibu hamil $(17,9 \%)$ dan kelompok paritas yang tidak berisiko (kurang dari 4) sebanyak 64 ibu hamil $(82,1 \%)$. Kelompok ibu yang tidak bekerja sebanyak 64 orang $(82,1 \%)$, dan ibu hamil yang bekerja sebanyak 14 orang $(17,9 \%)$.

\section{Tabel 1. Distribusi Responden berdasarkan Karakteristik Ibu di Puskesmas Mangasa Kota Makassar}

\begin{tabular}{lcc}
\hline Variabel & \multicolumn{2}{c}{ Kelompok Ibu Hamil } \\
\cline { 2 - 3 } Karakteristik Ibu & N & \% \\
\hline Umur Ibu Hamil & & \\
Berisiko & 25 & 32,1 \\
Tidak berisiko & 53 & 67,9 \\
Total & 78 & 100 \\
Paritas Ibu Hamil & & \\
Berisiko & 14 & 17,9 \\
Tidak berisiko & 64 & 82,1 \\
Total & 78 & 100 \\
Pekerjaan Ibu & & \\
Tidak bekerja & 64 & 82,1 \\
Bekerja & 14 & 17,9 \\
\hline Total & 78 & 100 \\
\hline Sumber: Data Sekunder Tahun 2018
\end{tabular}

Tabel 2. Distribusi Responden berdasarkan Kurang Energi Kronik pada Ibu Hamil di Puskesmas Mangasa Kota Makassar

\begin{tabular}{lcc}
\hline $\begin{array}{l}\text { Kurang Energi Kronik } \\
\text { pada Ibu Hamil }\end{array}$ & N & \% \\
\hline KEK & 57 & 73,1 \\
Tidak KEK & 21 & 26,9 \\
\hline Total & 78 & 100 \\
\hline Sumber: Data Sekunder Tahun 2018 &
\end{tabular}

Pada tabel 2 menunjukkan bahwa ibu hamil berjumlah 78 orang. Ibu hamil yang mengalami Kurang Energi Kronik (KEK) sebanyak 57 orang $(73,1 \%)$ dan ibu hamil yang tidak mengalami Kurang Energi Kronik (KEK) sebanyak 21 orang $(26,9 \%)$.

Tabel 3. Distribusi Responden berdasarkan Kejadian Anemia pada Ibu Hamil di Puskesmas Mangasa Kota Makassar

\begin{tabular}{lcc}
\hline Anemia pada Ibu Hamil & $\mathbf{N}$ & $\boldsymbol{\%}$ \\
\hline Anemia & 57 & 73,1 \\
Tidak Anemia & 21 & 26,9 \\
\hline Total & 78 & 100 \\
\hline
\end{tabular}

Sumber: Data Sekunder Tahun 2018

Pada tabel 3 menunjukkan bahwa ibu hamil berjumlah 78 orang. Ibu hamil yang mengalami anemia sebanyak 57 orang $(73,1 \%)$ dan ibu hamil yang tidak mengalami anemia sebanyak 21 orang $(26,9 \%)$.

Tabel 4. Hubungan Kurang Energi Kronis dengan Kejadian Anemia pada Ibu Hamil di Puskesmas Mangasa Kota Makassar

\begin{tabular}{|c|c|c|c|c|c|c|}
\hline \multirow{3}{*}{$\begin{array}{c}\text { Kurang } \\
\text { Energi } \\
\text { Kronik }\end{array}$} & \multicolumn{4}{|c|}{ Kejadian Anemia } & \multirow{2}{*}{\multicolumn{2}{|c|}{ Jumlah }} \\
\hline & \multicolumn{2}{|c|}{ Anemia } & \multicolumn{2}{|c|}{$\begin{array}{c}\text { Tidak } \\
\text { Anemia }\end{array}$} & & \\
\hline & $\mathbf{n}$ & $\%$ & $\mathbf{n}$ & $\%$ & $\mathbf{N}$ & $\%$ \\
\hline KEK & 47 & 60,3 & 10 & 12,8 & 57 & 73,1 \\
\hline Tidak KEK & 10 & 12,8 & 11 & 14,1 & 21 & 26,9 \\
\hline Total & 57 & 73,1 & 21 & 26,9 & 78 & 100 \\
\hline \multicolumn{7}{|c|}{ Tilai $p(0,005)<\alpha(0,05)$} \\
\hline
\end{tabular}

Berdasarkan tabel 4. menunjukkan bahwa dari 78 ibu hamil yang mengalami Kurang Energi Kronik sebanyak 57 orang. Dari jumlah tersebut 47 ibu hamil $(60,3 \%)$ yang mengalami anemia dan $10 \mathrm{ibu}$ hamil $(12,8 \%)$ yang tidak menglami anemia. Kemudian untuk ibu hamil yang tidak mengalami Kurang Energi Kronik (KEK) berjumlah 21 orang, dimana dari jumlah ibu hamil yang mengalami anemia berjumlah 10 orang $(12,8 \%)$, dan yang tidak mengalami anemia berjumlah 11 orang $(14,1 \%)$.

Berdasarkan hasil analisis statistik dengan menggunakan uji Chi Square (Continuity Correction) menunjukkan nilai $p$ $(0,005)<\alpha(0,05)$, artinya nilai $p$ lebih kecil dari nilai $\alpha$ pada derajat kepercayaan $95 \%$ 
dengan derajat kebebasan 1. Hal ini dapat disimpulkan bahwa hipotesis nol ditolak dan hipotesis alternatif diterima ini berarti terdapat hubungan antara Kurang Energi Kronik dengan kejadian anemia pada Ibu Hamil.

\section{PEMBAHASAN}

Penelitian ini dimaksudkan untuk menilai hubungan Kurang Energi Kronik dengan kejadian anemia pada ibu hamil di Puskesmas Mangasa Kota Makassar. Berdasarkan hasil penelitian menunjukkan bahwa dari 78 ibu sebagai subjek penelitian, didapatkan ibu mengalami Kurang Energi Kronik (KEK) sebanyak 57 ibu hamil $(73,1 \%)$, dan ibu hamil yang tidak mengalami KEK sebanyak 21 orang $(26,9 \%)$. Pada hasil analisis data terdapat pula $10(12,8 \%)$ ibu hamil KEK yang tidak mengalami anemia dan $10(12,8 \%)$ ibu hamil yang mengalami anemia tetapi tidak KEK, hal ini dipengaruhi oleh cara menjaga zat besi di dalam makanan tidak disertai dengan konsumsi makanan ataupun konsumsi air putih yang dapat membantu penyerapan zat besi, karena apabila ibu mengkonsumsi kafein dapat menghambat zat besi (Aminin et al., 2014). Hal ini terjadi disebabkan karena adanya ketidakseimbangan asupan gizi yang telah berlangsung lama (Kemenkes RI, 2015).

Dari hasil penelitian, peneliti berasumsi bahwa sebagian besar ibu hamil mengalami KEK karena kurangnya pendidikan kesehatan sejak dini tentang asupan nutrisi yang mengandung gizi seimbang. Seorang yang berniat hamil sudah harus mempersiapkan pola makan yang baik sejak sebelum hamil dan berada dalam status gizi yang normal. Banyak faktor yang mempengaruhi antara lain kemampuan keluarga dalam membeli makanan, ngidam merupakan pertanda bahwa dalam tubuh ibu hamil ada perubahan besar yang menyangkut susunan enzim dan hormon. Dengan demikian tubuh ibu menjadi lebih efisien menyerap zat gizi dari makanan seharihari. Pada ibu hamil dianjurkan minum dan makan-makanan yang segar misalnya buah segar, sayuran atau selada buah/sayuran. Akan tetapi status ekonomi dan status sosial sangat mempengaruhi seorang wanita dalam memilih makanannya.

Berdasarkan hasil penelitian ibu hamil berjumlah 78 orang dan Ibu hamil yang mengalami anemia sebanyak 57 orang $(73,1 \%)$ dan ibu hamil yang tidak mengalami anemia sebanyak 21 orang $(26,9 \%)$. Anemia pada ibu hamil erat kaitannya dengan status gizi ibu hamil karena anemia merupakan salah satu tanda bahwa ibu kekurangan gizi (Kemenkes RI, 2017) (Sutanto \& Fitriana, 2015).

Dari hasil penelitian ini, peneliti berpendapat bahwa ibu hamil yang mengalami anemia disebabkan karena beberapa faktor salah satunya kepatuhan dalam mengkonsumsi tablet $\mathrm{Fe}$ atau makanan yang mengandung zat besi, frekuensi antenatal juga sangat mempengaruhi status anemia karena petugas dapat memberikan penyuluhan tentang informasi gizi selama hamil dan ibu diberi tablet tambah darah secara gratis.

Berdasarkan hasil analisis statistik dengan menggunakan uji Chi Square (Continuity correction) menunjukkan bahwa hipotesis nol ditolak dan hipotesis alternatif diterima ini berarti terdapat hubungan antara Kurang Energi Kronik dengan kejadian anemia pada ibu hamil. Masalah gizi yang sering dihadapi ibu hamil yaitu KEK dan anemia sedangkan anemia pada ibu hamil erat kaitannya dengan status gizi ibu hamil karena anemia merupakan salah satu tanda bahwa ibu menderita kekurangan gizi. Anemia pada wanita hamil memiliki dampak yang buruk, baik terhadap ibu maupun janin. Ibu hamil yang menderita anemia berat memungkinkan terjadinya partus premature serta memiliki bayi dengan berat lahir rendah yang dapat mengakibatkan kematian (Ariyani, 2016).

Penelitian yang telah dilakukan mendapatkan hasil sesuai dengan hipotesis yang disusun dalam penelitian ini yaitu ada hubungan antara kekurangan energi kronik dengan kejadian anemia pada ibu hamil, dengan $p$ value $=0,005$ yang $<$ dari $\alpha 0,05$ sehingga Ha diterima dan Ho ditolak. Hasil penelitian ini sejalan dengan penelitian yang dilakukan oleh (Widya Larasati, 2018) bahwa dari 199 responden ibu hamil di RSKDIA Sitti Fatimah Makassar tahun 2018 terdapat responden yang KEK sebanyak 37 dimana terdapat $6(3,0 \%)$ ibu hamil yang anemia dan $31(15,6 \%)$ ibu hamil yang tidak anemia. Dari 162 responden yang tidak KEK terdapat $4(2,0 \%)$ ibu hamil yang anemia dan $158(79,4 \%)$ ibu hamil yang tidak anemia. Hasil penelitian ini menunjukkan bahwa ada hubungan antara KEK dengan kejadian anemia pada ibu hamil di RSKDIA Sitti Fatimah Makassar tahun 2018. 


\section{KESIMPULAN DAN SARAN}

Berdasarkan hasil penelitian maka dapat ditarik kesimpulan bahwa Kejadian Kurang Energi Kronik (KEK) pada ibu hamil di Puskesmas Mangasa Kota Makassar sebanyak $73,1 \%$ (57 orang) dari 78 orang ibu hamil, sedangkan Kejadian anemia pada ibu hamil di Puskesmas Mangasa Kota Makassar sebanyak $73,1 \%$ (57 orang) dari 78 orang ibu hamil. Pada hasil penelitian diperoleh bahwa terdapat hubungan Kurang Energi Kronik (KEK) dengan kejadian anemia pada ibu hamil di Puskesmas Mangasa Kota Makassar. Dari hasil penelitian yang telah diperoleh maka peneliti akan merencanakan pengabdian kepada masyarakat dalam hal ini sosialisasi untuk memberikan kontribusi dalam upaya menurunkan angka prevalensi kejadian KEK pada ibu hamil.

Disarankan kepada Petugas kesehatan agar dapat melakukan pemantapan KIE yang berkesinambungan pada ibu hamil dengan risiko KEK dan anemia untuk lebih memperhatikan status kesehatannya dari segala faktor termasuk dalam kesiapan menghadapi kehamilan dengan pendekatan lintas sektoral.

\section{DAFTAR PUSTAKA}

Aminin, F., Wulandari, A., \& Lestari, R. P. (2014). Pengaruh Kekurangan Energi Kronis (KEK) Dengan Kejadian Anemia Pada Ibu Hamil. Jurnal Kesehatan, 5(2), 167-172. https://doi.org/ 10.26630/ jk.v5i2.52

Ariyani, R. (2016). Faktor-Faktor yang Mempengaruhi Kejadian Anemia pada Ibu Hamil Trimester III di Wilayah Kerja Puskesmas Mojolaban Kabupaten Sukoharjo [Universitas Muhammadiyah Surakarta]. http://eprints.ums. ac.id/
42421/1/NASKAH PUBLIKASI.pdf

Infodatin. (2014). Pusat Data dan Informasi Kementrian Kesehatan RI).

Kemenkes RI. (2015). Pedoman Penanggulangan Kurang Energi Kronik. Direktorat Bina Gizi Dan Direktorat Jendral Bina Gizi Kesehatan Ibu Dan Anak.

Kemenkes RI. (2017). Hasil Pemantauan Status Gizi (PSG) dan Penjelasannya Tahun 2016.

Kemenkes RI. (2018). Laporan Kinerja Ditjen Kesehatan Masyarakat Tahun 2017.

Prawirohardjo, S. (2016). Ilmu Kebidanan. Yayasan Bina Pustaka Sarwono Prawirohardjo.

Puskesmas Mangasa. (2018). Laporan Data Puskesmas.

RISKESDAS. (2018). Hasil Utama RISKESDAS 2018.

Sutanto, A. V., \& Fitriana, Y. (2015). Asuhan Pada Kehamilan. Pustaka Baru Press.

WHO. (2015). From MDGs to SDGs. Geneva World Health Organization.

Widya Larasati, E. (2018). Hubungan antara Kekurangan Energi Kronis (KEK) terhadap Kejadian Anemia pada Ibu Hamil di RSKDIA Siti Fatimah Makassar 2018. Jurnal Kesehatan Delima Pelamonia, 2(2), 131-134. https://doi.org/10.37337/jkdp.v2i2.79

Wijayanti, H. (2016). Faktor-faktor yang Berhubungan dengan Kekurangan Energi Kronik (KEK) pada Ibu Hamil di Puskesmas Jetis II Bantul Yogyakarta [Universitas 'Aisyiyah Yogyakarta]. http://digilib.unisayogya.ac.id/1996/. 